\title{
Perlindungan Tenaga Kerja Indonesia di Luar Negeri Melalui Sertifikasi Kompetensi
}

\author{
Ahmad Firdaus Sukomono \\ Faculty of Law, Al-Azhar Islamic University of Mataram, Indonesia \\ afsukmono@yahoo.com
}

Submitted: 2016-11-14; Reviewed: 2017-05-05; Accepted: 2017-06-06

\begin{abstract}
With so many Indonesian Workers who work abroad showed that the government's ability to provide jobs is very limited. Statistical news 2016 states that the number of placement of Indonesian workers abroad in 2016 amounted to 153. 804 with details of Indonesian manpower formal 82.443 Indonesian workers and informal 71.361 Indonesian workers. Comparing the two types of workers in the formal and informal sectors, the subject-matter of the author adopted is to provide protection to informal workers thus have a legal position that is better and stronger through a certificate of competence so as to protect the rights of workers and bargaining power balanced between giver employers and workers.
\end{abstract}

Keywords: Certificate of Competency; Indonesia Labor; Legal Protection.

\section{PENDAHULUAN}

Masyarakat dunia dan di Indonesia khususnya mengalami sebuah transformasi dari masyarakat yang berbasis agraris menuju masyarakat industri. Perubahan tersebut mengalami akselerasi semenjak penggunaan teknologi menjadi modus utama penyelesaian permasalahan. Sehingga mobilitas tenaga kerja tidak hanya perpindahan dari desa ke kota bahkan sudah menembus batas antar negara. Banyak hal yang dapat mempengaruhi terjadinya migrasi antar negara, namun faktor ekonomi tetap tampak dominan.

Faktor ekonomi inilah yang mendorong masyarakat untuk bekerja sebagai sarana memperoleh pendapatan atau penghasilan dalam rangka memenuhi hajat hidupnya. Salah satu persoalan yang paling mendasar dalam kehidupan masyarakat adalah pekerjaan dan lapangan kerja. Ketersediaan lapangan kerja bagi kepentingan masyarakat merupakan suatu yang sangat mendasar sehingga untuk menjaga ketersediannya negara harus melakukan berbagai upaya untuk menjaga tetap berlangsungnya kegiatan ekonomi negara maupun ekonomi masyarakat. Dalam rangka memperluas lapangan kerja dan melindungi masyarakat pekerja Pemerintah bersama-sama Dewan Perwakilan Rakyat (DPR) telah banyak mengeluarkan peraturan perundang-undangan seperti 
undang-undang, peraturan pemerintah, peraturan presiden, peraturan menteri dan lain sebagainya.

Negara Indonesia memiliki jumlah penduduk sekitar 250 juta orang, menurut berita statistik tahun 2016 jumlah penempatan Tenaga Kerja Indonesia (TKI) tahun 2016 adalah sebesar 153.804 orang dengan rincian 82.443 orang TKI formal dan 71.361 TKI informal. ${ }^{1}$ Dari jumlah tersebut tercatat 96.042 merupakan perempuan dan 57.762 merupakan lakilaki.

Dengan begitu banyaknya TKI yang bekerja diluar negeri menunjukan bahwa kemampuan pemerintah dalam menyediakan lapangan pekerjaan sangat terbatas, walaupun penyediaan lapangan kerja adalah merupakan amanat UndangUndang Dasar 1945 sebagaimana tersebut di dalam Pasal 2. Selain pemerintah masyarakat melalui perusahaan atau kegiatan usaha dapat menciptakan lapangan kerja namun jumlahnya juga terbatas sesuai dengan kondisi perekonomian yang ada.

Sinergi antara pemerintah dengan masyarakat khususnya pada masyarakat dunia usaha, sampai saat ini cukup baik namun mengingat sumber-sumber lain yang dapat menciptakan dan memperluas lapangan kerja terbatas, dimana laju pertumbuhan jumlah lapangan kerja dengan laju pertumbuhan jumlah angkatan kerja tidak sebanding, perluasan lapangan kerja cenderung lebih rendah dari peningkatan jumlah angkatan kerja. Seperti diketahui bahwa selain lapangan pekerjaan yang ada pada Pemerintah dan swasta

\footnotetext{
${ }^{1}$ http://www.bnp2tki.go.id/ Data Penempatan dan Perlindungan TKI Periode Bulan Agustus Tahun 2016.
}

(dunia usaha), masyarakat rumah tangga juga membuka lapangan kerja pada sektor informal (pembantu rumah tangga).

Menurut WTO (World Trade Organization) di dalam perdagangan dunia dikenal dengan istilah: Pertama, Perdagangan Barang (Trade in Good); Kedua, Perdagangan Jasa (Trade in Services). Dan sektor tenaga kerja adalah merupakan kelompok yang diatur dibawah payung Perdagangan Jasa (Trade in Services), disamping itu juga pengaturan tenaga kerja secara internasional berada dibawah payung ILO (International Labor Organization), organisasi buruh internasional.

Dalam perdagangan jasa (Trade in Service) dikenal empat jenis mode perdagangan jasa: ${ }^{2}$

a. Mode 1 (cross border supply), take place when a services is supplied from the territory of one Member into the territory of any other Member. That is, the service is rendered by resident in one economic territory to a resident of another economic territory and only services "cross the border." (Contohnya adalah jual beli buku secara online).

b. Mode 2 (consumption abroad), occurs when the service supplied "in the territory of one Member to the service consumer of any Member". That is the consumer consumes the service outside his/her home territory. (perdagangan antar negara melalui kunjungan wisatawan untuk melihat dan menikmati obyek

\footnotetext{
${ }^{2}$ General Agreement on Tarde in Services Chapter XX
} 
pariwisata).

c. Mode 3 (commercial presence) takes place through the supply of a service supplier of one Member through commercial presence in the territory of any other Member. (penjualan jasa dari suatu negara ke negara lain melalui layanan purna jual, tenaga akhli untuk kepentingan investasi dibidang industri maupun investasi dibidang jasa rumah sakit dan lain sebagainya).

d. Mode 4 (presence of natural persons), occurs when an individual is temporarily present in the territory of an economy other than his own to provide a commercial service. (Contohnya adalah tenaga kerja asing yang bekerja diluar negeri dengan menjual keakhlian atau expertise tertentu).

Lebih lanjut perjanjian perdagangan jasa dalam kerangka GATS (General Agreement on Trade in Services) yang tersebut di dalam 4 mode di atas merupakan definisi dari jenis lalu lintas perdagangan jasa. Jenis perdagangan mode 4 adalah perdagangan jasa tenaga kerja asing baik yang masuk ke Indonesia maupun tenaga kerja Indonesia yang pergi bekerja di luar negeri.

Peningkatan jumlah tenaga kerja Indonesia yang bekerja diluar negeri disebabkan oleh banyaknya permintaan tenaga kerja Indonesia dari luar negeri, namun sangat disayangkan dari populasi tenaga kerja Indonesia yang bekerja diluar negeri, adalah kebanyakan tenaga kerja yang tidak memiliki keterampilan dan kompetensi atas sebuah pekerjaan tertentu.

Tenaga kerja Indonesia yang bekerja diluar negeri dikatagorikan sebagai perdagangan jasa lintas negara mode 4 yaitu presence of natural persons yaitu seorang datang keluar negeri untuk bekerja berdasarkan keakhlian tertentu, namun demikian pada kenyataanya tenaga kerja Indonesia yang keluar negeri sebagian besar bekerja disektor informal, seperti menjadi pekerja di rumah tangga penduduk setempat, buruh di perkebunan. Untuk mengerjakan kedua jenis pekerjaan ini tidak untuk memiliki keahlian tertentu, hampir setiap orang dewasa dapat melakukannya, sepanjang memiliki tenaga dan sehat jasmani dan rohani.

Dasar atau kualifikasi pendidikan untuk melakukan pekerjaan tersebut hampir tidak ada dan yang diperlukan adalah yang bersangkutan bisa membaca dan menulis dalam bahasa ibu, masing-masing asal negara pekerja, sehingga tingkat pendidikan formal tertentu tidak banyak diperlukan. Memperoleh pekerjaan diluar negeri sangat tidak mudah, sebagian besar pekerja non formal bekerja diluar negeri berdasarkan permintaan dan pola rekruitmen tertentu, tidak diperlukan lamaran pekerjaan dan sangat tergantung kepada kebutuhan pasar dinegara pemberi kerja.

Sebagai akibatnya posisi tawar penerima kerja dan pemberi kerja menjadi tidak seimbang, pemberi kerja karena memiliki posisi tawar yang tinggi cenderung untuk semena-mena menentukan kontrak kerja, upah kerja dan hal lain yang terkait dengan perjanjian kerja, selain itu karena jumlah tenaga kerja yang tersedia lebih banyak dari permintaan maka posisi tawar pemberi kerja makin kuat.

Rekrutmen tenaga kerja sektor informal 
di Indonesia biasanya dilakukan oleh agen tenaga kerja yang memperoleh ijin dari pemerintah yang dalam hal ini Kementrian tenaga kerja dan Pemerintah Daerah setempat. Persyaratan yang diperlukan untuk dapat bekerja diluar negeri sangat sederhana, persyaratan yang paling sulit diperoleh adalah dokumen perjalanan dan tentunya visa atau ijin masuk kenegara tujuan, setelah memperoleh dokumen perjalanan para pekerja secara kolektip dikirim keluar negeri dengan dibekali surat keterangan yang dikeluarkan oleh agen di Indonesia yang untuk diberikan kepada agen pemberi kerja diluar negeri.

Kontrak kerja dan negosiasi perjanjian kerja antara pekerja dan pemberi kerja sebagian besar dilakukan antar agen pemberi kerja dan penerima kerja, jarang terjadi pekerja melakukan kontrak secar langsung dengan pemberi kerja, tidak seperti pekerja disektor formal (Perawat, Dokter, Akuntan dan tenaga akhli lainnya) yang biasanya memiliki posisi tawar yang seimbang antara pekerja dan pemberi kerja. Hal ini terjadi karena: Pertama, demand dan supply antara pemberi kerja dan pekerja relatif seimbang: Kedua, pekerja pada sektor formal adalah orang-orang terdidik dan mempunyai keahlian yang tidak banyak dimiliki orang: Ketiga, pekerja sektor formal dianggap sebagai pekerja subsitusi atau pengganti pekerja sejenis di negara pemberi kerja, misalnya jumlah orang berminat menjadi perawat kurang karena pekerjaan perawat sudah tidak disukai dingera tersebut, sehingga lulusan perawat cenderung berkurang.

Peran pemerintah didalam melindungi pekerja Indonesia yang ada diluar negeri sangat besar, berbagai peraturan dan kebijakan pemerintah dikeluarkan untuk memberi perlindungan kepada pekerja, keberpihakan stake holder atau pemangku kepentingan terhadap masalah tenaga kerja informal yang bekerja diluar negeri sangat besar, hal ini terlihat dari sikap bersama antara Pemerintah, LSM (Lembaga Swadaya Masyarakat) dan lembaga lainnya untuk mewujudkan jaminan perlindungan dan upah pekerja yang sesuai dengan pekerjaan yang dilakukan dan pada gilirannya akan memberikan kesejahteraan yang lebih baik bagi dirinya sendiri dan keluarganya.

Selain mengatur masalah ketenagakerjaan melalui peraturan dan kebijakan, Pemerintah juga menyediakan fasilitas pelatihan keterampilan tertentu untuk calon tenaga kerja non formal di luar negeri, mendorong perusahaan pengerah tenaga kerja untuk memperbaiki pola hubungan dengan agen pemberi kerja sekaligus hubungan dengan calon pekerja, sehingga hak-hak pekerja dapat dijaga dan diperoleh dengan baik termasuk penyediaan fasilitas peningkatan keterampilan calon pekerja dan kegiatan pengenalan atau orientasi kerja diluar negeri.

Membandingkan dua jenis pekerja diatas (sektor formal dan informal) maka pokok permasalahan yang penulis angkat adalah bagaimana memberikan perlindungan kepada pekerja informal sehingga memiliki kedudukan hukum yang lebih baik dan kuat sehingga dapat melindungi hak-hak pekerja dan memiliki posisi tawar yang seimbang antara pemberi kerja dan pekerja. Dalam penelitian ini akan dianalisa apakah dengan pemilikan kompetensi seorang pekerja informal dapat melindungi dirinya secara hukum terhadap hak-hak dan kewajibannya. 


\section{PEMBAHASAN}

\section{Perlindungan dan Persoalan Tenaga Kerja Informal di Luar Negeri}

Pemberian perlindungan oleh Negara kepada rakyatnya merupakan kewajiban sebagaimana yang diamanatkan oleh konstitusi, dalam pembukaan Undangundang Dasar Negara tahun 1945, alinea ke-empat menyebutkan;

“.........Kemudian daripada itu untuk membentuk suatu pemerintah negara Indonesia yang melindungi segenap bangsa Indonesia dan seluruh tumpah darah Indonesia dan untuk memajukan kesejahteraan umum mencerdaskan kehidupan bangsa, dan ikut melaksanakan ketertiban dunia yang berdasarkan kemerdekaan, perdamaian abadi dan keadilan sosial."

Kalimat melindungi segenap bangsa Indonesia memiliki makna dan pengertian yang sangat mendalam, makna melindungi adalah perlindungan terhadap individu warganegara dalam segenap aspek kehidupan dari upaya penindasan maupun eksploitasi semena-mena dari pihak lain, sedangkan pengertian perlindungan adalah menjaga dan memberikan kesempatan seluas-luasnya untuk memperoleh kehidupan dan penghidupan layak sebagai manusia.

Dalam upaya memberi penghidupan yang layak maka Pemerintah atau Negara sesuai dengan amanat Pasal 33 ayat (3) UUD 1945 diberikan hak dan wewenang penuh atas kekayaan alam Indonesia (bumi, air dan kandungan didalamnya) yang dipergunakan untuk kepentingan umum dan kesejahteraan masyarakat seluas luasnya.
Lebih lanjut, sebagai upaya memberi penghidupan yang layak oleh Negara kepada rakyatnya, UUD mengamanatkan dalam Pasal 27 ayat (2) bahwa; "Tiap-tiap warga negara berhak atas pekerjaan dan penghidupan yang layak bagi kemanusiaan". Terdapat dua kata kunci perintah dalam kalimat tersebut, yaitu; Pertama, negara menyediakan pekerjaan dan memberikan penghidupan yang layak. Penyediaan lapangan kerja adalah perintah UUD yang harus dilaksanakan oleh negara yang dalam hal ini adalah Pemerintah, penyediaan lapangan kerja dalam arti luas adalah Pemerintah memfasilitasi terbukanya lapangan kerja bagi masyarakat angkatan kerja atau masyarakat usia kerja atau Pemerintah membuka lowongan kerja bagi masyarkat untuk bekerja pada pemerintah menjadi PNS, Pegawai Honor dan lain sebagainya. Dengan bekerjanya warga maka secara langsung atau tidak langsung akan terpenuhi kehiduapanya yang layak atau sesuai standard hidup minimal.

Kedua, pemberian penghidupan yang layak bagi kemanusian artinya pemerintah secara penuh memberi penghidupan yang layak apabila tidak dapat memperolehnya sendiri. Tanggung jawab pemerintah didalam memberikan penghidupan yang layak tidak serta merta diartikan sebagai tanggung jawab secara harafiah namun lebih merupakan tanggung jawab sosial, termasuk didalamnya tanggung jawab masyarakat secara luas dan perusahaan atau dunia usaha yang secara bersama sama menikmati fasilitas umum yang disediakan oleh pemerintah.

Melalui Undang-undang Nomor 13 Tahun 2003 tentang Ketenagakerjaan dan berbagai peraturan yang mengikutinya, 
pemerintah baik ditingkat pusat sampai daerah, mengatur distribusi lapangan kerja bagi masyarakat, mengatur tata hubungan antara pekerja dan pemberi kerja, mengatur tata cara pengupahan dan standard nasional dan regional pengupahan dan lain sebagainya yang terkait dengan urusan ketenaga kerjaan.

Selain itu juga pemerintah melalui Peraturan Pemerintah dan peraturan dibawahnya juga mengatur standard kompetensi dan mengatur tentang tata cara penyediaan tenaga kerja luar negeri baik sektor formal maupun informal serta juga mengatur lalu lintas pekerja asing yang keluar masuk wilayah Indonesia untuk melakukan suatu pekerjaan tertentu.

Dalam dua dekade yang lalu, sering sekali muncul pemberitaan mengenai persoalan tenaga kerja informal Indonesia diluar negeri (TKI), tidak semua berita negatif yang disampaikan, berita keberhasilan atau success stories pekerja Indonesia informal di Luar Negeri juga disampaikan walaupun sangat jarang. ${ }^{3}$ Setiap kali membaca dan mendengar berita mengenai TKI, yang ada adalah berita kesedihan dan kesulitan dari para TKI yang ada diluar negeri, selain masalah sosial masyarakat seperti perkelahian, penyiksaan dan penipuan juga masalah pidana dan pengurangan hak-hak pekerja dari yang seharusnya diterima seperti gaji atau upah, cuti, perpanjangan kontrak, pekerjaan yang harus dilakukan dan yang tidak dilakukan, pembagian waktu kerja dan lain sebagainya.

Persoalan-persoalan diatas sudah menjadi klise dan hal yang jamak atau

\footnotetext{
${ }^{3}$ Selama periode 1 Januari - 31 Maret 2014 jumlah WNI yang mengalami kasus di Luar Negeri yang tercatat pada Direktorat Perlindungan WNI dan BHI
}

biasa, sehingga masyarakat sudah tidak melihatnya lagi sebagai persoalan hukum, sosial maupun moral secara khusus dan sudah dianggap sebagai peristiwa yang harus dialami dan dirasakan oleh TKI apabila menjadi TKI informal diluar negeri.

Akar permasalahan timbulnya masalah TKI informal diluar negeri adalah karena posisi tawar antara pemberi kerja dan penerima kerja memiliki gap yang sangat lebar. TKI informal diluar negeri adalah merupakan pekerja pada strata terendah diantara urutan tenaga kerja diluar negeri, pembagian strata pekerjaan baik diluar negeri ataupun didalam negeri tidak banyak perbedaannya dan nyaris sama, hal ini terjadi karena pada hakekatnya kehidupan dan kebutuhan hidup manusia pada dasarnya sama sehingga pekerjaan yang dilakukan tiap-tiap orang ditiap-tiap negara sama, contohnya ada pekerjaan sebagai pegawai pemerintah ada pekerjaan sebagai pegawai swasta ada pekerjaan sebagai wiraswasta ada jenis pekerjaan disektor formal ada pekerjaan informal dan lain sebagainya.

Persoalan yang timbul antara pemberi kerja dan pekerja disektor informal selain karena masalah posisi tawar yang timpang juga disebabkan ruang lingkup yang dikerjakan oleh pekerja sangat luas dan cenderung bervariasi atau jenisnya banyak, sebagai contoh seorang yang bekerja sebagai pembantu rumah tangga diluar negeri akan berhasil atau tidak menjalankan tugasnya tergantung kepada siapa majikan atau pemberi kerja, maksudnya status sosialnya di masyarakat,

adalah sebanyak 7.222 orang dengan total jumlah kasus sebanyak 8.184 kasus (catatan : 1 orang WNI dapat mengalami lebih dari 1 jenis kasus). 
luas rumah, jumlah anggota keluarga yang tinggal dan seterusnya.

Status sosial pemberi kerja akan sangat berpengaruh terhadap pola hubungan antara pekerja dan pemberi kerja, kemudian luas rumah dan anggota keluarga yang tinggal akan sangat berpengaruh terhadap pola kerja dan ritme kerja seorang pembantu dan kemudian adalah jumlah atau item pekerjaan yang harus dilakukan juga sangat berpengaruh terhadap cara kerja dari seorang pekerja. Kesemua variabel tersebut akan sangat sulit dituangkan didalam perjanjian atau kontrak kerja dan cenderung dirangkum dalam suatu sebutan pembantu umum atau pembantu rumah tangga.

Semakin luas cakupan pekerjaan (umum) didalam sebuah perjanjian kerja akan semakin mengaburkan norma yang ada didalam perjanjian para pihak. Persoalan lain akan muncul lagi karena pihak-pihak yang melakukan perjanjian adalah melalui para masing-masing agen. Kekaburan norma yang muncul akibat luasnya cakupan pekerjaan cenderung akan menguntungkan pihak yang lemah yang dalam hal ini adalah pekerja.

\section{Upaya Perlindungan Tenaga Kerja Melalui Kompetensi}

Sebagaimana yang diamanatkan di dalam Peraturan Perundang-undang baik UUD maupun undang-undang yang berada dibawahnya, bahwa setiap Warga Negara Indonesia harus mendapat perlindungan dari Negara dalam rangka menjalankan kehidupannya sehari-hari. Perlindungan yang diberikan oleh pemerintah adalah secara pisik (ketersediaan kebutuhan hidup), non pisik (perlindungan hukum dan ancaman keamanan pihak lain) dan lain sebagainya.

Persoalan TKI Informal Indonesia di luar negeri yang timbul adalah juga menjadi persoalan negara baik secara langsung maupun tidak langsung, sehingga apapun permasalahan yang timbul, pemerintah berkewajiban untuk ikut campur baik dalam tindakan observasi, monitoring, pengawasan, pemberian bantun moril (bantuan hukm pengamanan dan lainnya) maupun materiil (pemberian santunan fasilitasi pemulangan dan lain sebagainya). Pemberian tersebut adalah merupakan bentuk perlindungan negara kepada warganya yang lebih bersifat ad hoc atau sementara ketika persoalan timbul.

Namun jika terjadi pengulangan masalah yang berkali kali maka perlu diupayakan bentuk perlindungan yang lain sehingga dapat mengurai masalah yang akan muncul dan menyeimbangkan posisi tawar antara pemberi kerja dan pekerja. Sebagaimana disebutkan diatas bahwa posisi tawar yang tidak seimbang adalah disebabkan adanya kekaburan norma yang terjadi akibat dari generalisasi cakupan lingkup pekerjaan yang harus dikerjakan oleh pekerja.

Upaya yang dilakukan didalam memperjelas norma yang kabur tadi maka cakupan pekerjaan yang begitu luas harus dipersempit dengan menyebutkan item demi item yang harus dikerjakan sehingga walaupun daftar pekerjaan yang harus dikerjakan jumlahnya terlihat banyak namun tidak lagi menimbulkan kekaburan norma dan sekaligus dapat menyadarkan pekerja atas pekerjaan yang akan dilakukan sebelum melakukan penanda tanganan kontrak kerja atau perjanjian kerja.

Penyebutan jenis pekerjaan rumah tangga yang secara eksplisit tentu akan 
menimbulkan pertanyaan pengujian oleh pihak pemberi kerja baik secara langsung maupun melalui agen pengerah tenaga kerja, apakah calon pekerja tersebut mampu dan sanggup untuk menjalankannya.

Pembuktian akan kemampuan sesorang untuk melakukan suatu pekerjaan tertentu pada umumnya dilakukan oleh lembaga tertentu yang ditunjuk oleh negara atau pemerintah pusat maupun daerah. Tugas dari lembaga tersebut adalah menguji dan sekaligus mensertifikasi kompetensi seseorang dalam bidang pekerjaan tertentu. Sebagai contoh kompetensi dibidang pengelolaan rumah tangga, kompetensi dibidang house keeping (pembersihan rumah dll) dan lain sebagainya.

Dengan berbekal sertifikat ataupun pengakuan keahlian dibidang tersebut maka tugas dan fungsi pekerja rumah tangga akan secara eksplisit akan disebutkan didalam perjanjian kerja dimaksud, sehingga norma pembagian tugas dan fungsi serta hak dan kewajiban pemberi dan penerima kerja akan menjadi jelas dan menghilangkan kekaburan norma didalam perjanjian.

Pemberian kompetensi tersebut adalah merupakan salah satu upaya perlindungan yang dilakukan oleh pemerintah atau negara kepada warganya yang menjadi pekerja informal diluar negeri karena secara langsung akan dapat memberikan kepastian kepada kedua belah pihak pemberi kerja dan pekerja atas hak dan kewajiban masing masing pihak. Diharapkan dengan jelasnya norma yang ada didalam perjanjian dimaksud aturan main diantara kedua belah pihak akan diataati dan pada gilirannya akan mengeliminir permasalahan negative yang timbul diwaktu yang akan datang. Sehingga apabila terjadi dispute antar negara khususnya sesama anggota WTO atau negara lain penyelesaiannya relative lebih mudah karena ketika mengajukan tuntutan satu sama lain akan menggunakan article yang sama misalnya Chapeter XX GATS yang menyebutkan mode 4 dari definisi perdagangan jasa yang dilakukan oleh perseorangan diluar negeri.

\section{PENUTUP}

Kompetensi adalah merupakan persyaratan dasar yang terkandung didalam normanorma pengaturan tenaga kerja. Untuk dapat memenuhi perjanjian secara utuh maka tenaga kerja harus memiliki kompetensi yang diperlukan sebagaimana norma yang ada dalam perjanjian tenaga kerja. Kepemilikan kompetensi bagi tenaga kerja sektor informal diluar negeri akan secara langsung dapat memberikan kedudukan hukum yang kuat dan sekaligus memberi perlindungan terhadap perlakuan yang tidak adil yang didapatkan selama ini. Persoalan ketenagakerjaan adalah keterkaitan antara sektor swasta, hajat hidup masyarakat dan pemerintah, pengaturan ketenagakerjaan harus dilakukan secara integrative dan komprehensip. Walaupun Pemerintah didalam hal ini memiliki peran yang sangat strategis tidak berarti beban tanggung jawab persoalan tenanga kerja hanya ada pada pemerintah, partisipasi berbagai pihak swasta dan masyarakat luas yang berkepentingan harus terlibat didalam memikul tanggung jawab tersebut.

\section{DAFTAR PUSTAKA}

Mc Dougall, Macroeconomics, Mc Grow Hill-Education, 1981 
Dialogia luridica: Jurnal Hukum Bisnis dan Investasi

Volume 8 Nomor 2 April 2017

The Result of Uruguay Round of Secretariat Geneva, 1994

Multilateral Trade Negotiations, http://www.bnp2tki.go.id/ 